\title{
PENGEMBANGAN PERANGKAT PEMBELAJARAN PENJUMLAHAN DAN PENGURANGAN PECAHAN DESIMAL UNTUK KELAS V SEKOLAH DASAR DENGAN PENDEKATAN MATEMATIKA REALISTIK
}

\author{
${ }^{1}$ Nur Yum Saidah, ${ }^{2}$ Siti Maghfirotun Amin, ${ }^{3}$ Mustaji \\ ${ }^{1}$ Mahasiswa Program Pascasarjana, Prodi Pendidikan Dasar, Universitas Negeri Surabaya, \\ ${ }^{2 \& 3}$ Dosen Pascasarjana, Prodi Pendidikan Dasar, Universitas Negeri Surabaya \\ e-mail: nuryumsaidah@gmail.com
}

Received : November 2017

Reviewed: Desember 2017

Accepted : Januari 2018

Published : Januari 2018

\section{ABSTRACT}

The aim of this reseach is to describe learning device development process, to produce good learning device, and to describe the effectivity of device learning development in adding and subtracting decimal fraction using realistic mathematics in fifth grade at elementary school. This reseach using Plomp' model. This model have four phases: preliminary investigation, design, realization/constructio, test, evaluation, and revision; and implementation. This reseach produces: good learning device with criteria: (a) validity, the validator gives minal good apprasial at each document; (b) practice. Indicator of practicality of this device is teacher ability to manage the learning is in good category; (c) effectivity. Indicator of effectivity of this device is students activity fulfill effective criteria, suitable with ideal time and goal learning reach $82,75 \%$; (2) mathematic realistic are effectively with criteria; (a) clasical student learning result is $92,85 \%,(b)$ the teacher ability to manage the learning process is in good criteria. (c) the student activity fulfill effective criteria, (d) the student response of the learning process is positive

Keywords: learning device, Adding and substracting, decimal fraction, Realistic Mathematic.

\section{ABSTRAK}

Penelitian ini bertujuan untuk mendeskripsikan proses pengembangan perangkat pembelajaran, menghasilkan perangkat pembelajaran yang baik, dan mendeskripsikan keefektifan pembelajaran operasi penjumlahan dan pengurangan pecahan desimal di kelas $V$ Sekolah Dasar dengan pendekatan matematika realistik. Model pengembangan yang digunakan sebagai acuan adalah model Plomp. Model pengembangan ini meliputi lima fase yaitu fase investigasi awal (preliminary investigation), fase desain (design), fase realisasil konstruksi (realization/ construction), fase tes, evaluasi dan revisi (test, evaluation, and revision), dan fase implementasi (implementation). Penelitian ini menghasilkan (1) perangkat pembelajaran yang baik dengan kriteria : (a) kevalidan, hasil penilaian validator terhadap perangkat pembelajaran mencapai 82,75\%; (2) Pembelajaran matematika realistik untuk mengajarkan operasi penjumlahan adalah minimal dalam kategori baik; (b) kepraktisan, diindikasikan dengan kemampuan guru mengelola pembelajaran berada dalam kategori baik; (c) keefektifan, dengan indikator aktivitas siswa memenuhi kriteria efektif sesuai dengan waktu ideal dan ketuntasan hasil belajar siswa secara klasikal mencapai 82,75 \%; (2) Pembelajaran matematika realistik untuk mengajarkan operasi penjumlahan dan pengurangan pecahan desimal dengan kriteria : (a) hasil belajar siswa tuntas dengan persentase ketuntasan secara klasikal mencapai 92,85\%; (b) kemampuan guru mengelola pembelajaran berada dalam kategori baik; (c) aktivitas siswa memenuhi kriteria efektif; (d) respon siswa terhadap pembelajaran positif.

Kata Kunci: Perangkat Pembelajaran, Penjumlahan dan Pengurangan Pecahan, Desimal, Pendekatan Matematika Realistik. 


\section{PENDAHULUAN}

Salah satu bagian penting untuk mencerdaskan dan mengembangkan potensi pada diri manusia, dalam hal ini adalah siswa, yaitu dengan pembelajaran matematika. Matematika merupakan ilmu dasar dalam berbagai bidang dan memiliki peran penting dalam penguasaan ilmu dan teknologi. Menurut Hudoyo (dalam Suparmi, 2001:1) mengatakan bahwa penguasaan ilmu pengetahuan dan teknologi harus didasari oleh penguasaan matematika, karena penguasaan matematika merupakan kunci utama dalam menguasai ilmu dan teknologi.

Untuk merealisasikan tujuan pembelajaran matematika, khususnya di sekolah dasar maka dibutuhkan upaya dari berbagai pihak, salah satunya adalah guru. Guru memiliki tugas dan tanggungjawab yang begitu besar. Menurut Rohani (2004:1) tugas dan tanggungjawab seorang guru adalah mengelola pembelajaran dengan efektif, dinamis, efisien dan positif, yang ditandai dengan adanya kesadaran dan keterlibatan aktif diantara dua subjek pembelajaran, guru sebagai penginisiatif awal dan pengarah serta pembimbing, sedangkan siswa sebagai yang mengalami dan terlibat aktif dalam pembelajaran

Dijelaskan oleh Soejadi (2000:13) bahwa dalam matematika, objek dasar yang dipelajari adalah abstrak, sering juga disebut objek mental. Objek abstrak meliputi fakta, konsep, operasi dan prinsip abstrak.ini menujukkan bahwa pembelajaran matematika bukanlah obyek-obyek yang bisa langsung ditangkap oleh indera manusia.

Pendekatan pembelajaran yang kurang tepat dan keabstrakan objek matematika menjadi faktor penyebab sulitnya belajar matematika bagi para siswa. Untuk itu perlu dicari pendekatan yang melibatkan pemodelan dan pemanfaatan benda-benda di lingkungan siswa yang dapat memudahkan pemahaman mereka pada pembelajaran matematika. Salah satu pendekatan pembelajaran yang sesuai dengan itu adalah Pendidikan Matematika Realistik (PMR). Hadi (2005:19) mengemukakan bahwa Pendidikan Matematika Realistik pada dasarnya pemanfaatan realita dan lingkungan yang dipahami siswa untuk memperlancar proses pembelajaran matematika sehingga mencapai tujuan pendidikan matematika secara lebih baik.

Ruang lingkup mata pelajaran matematika pada satuan pendidikan SD/MI meliputi aspek: bilangan, geometri, pengukuran dan pengolahan data. Pada aspek bilangan terdapat pokok bahasan tentang pecahan. Materi pecahan dikenalkan sejak kelas tiga. Selanjutnya di kelas lima, materi pecahan membahas lebih lanjut tentang pecahan desimal.

Menurut Post (1992) pecahan desimal dapat dipandang dari dua perspektif yakni aspek sistem nilai tempat dengan basis sepuluh dan konsep pecahan. Ditinjau dari sistem nilai tempat dengan basis 10 , pecahan desimal mencakup persepuluhan, perseratusan, perseribuan, dst. Ditinjau dari konsep pecahan, pecahan desimal dapat dihubungkan dengan bagian suatu daerah (area-based part whole intrepretation). Dalam hal ini suatu daerah dibagi atas sepuluh bagian atau seratus bagian atau seribu bagian dst.

Masalah yang sering dihadapi dalam mempelajari konsep pecahan desimal ini yaitu kelemahan dalam penguasaan materi, tidak menyediakan dan tidak menggunakan alat peraga (media) serta penggunan metode pembelajaran yang kurang tepat. Guru hanya menggunakan metode ceramah dan pemberian tugas (drilling). Selain itu, dalam pembelajaran, guru tidak menggunakan masalah kontekstual yang dapat melibatkan siswa secara aktif. Hal ini menjadikan siswa kurang aktif, membingungkan dan akibatnya pembelajaran matematika menjadi kurang maksimal.

Menyadari hal tersebut, maka diperlukan suatu alternatif pendekatan pembelajaran yang tidak hanya berorientasi pada pencapaian nilai sesuai KKM, tetapi lebih kepada pemahaman siswa terhadap konsep dan prinsip matematika serta bagaimana cara memecahkan masalah matematika dan mampu mengaplikasikannya dalam kehidupan sehari-hari.

Dengan adanya penerapan pendekatan Pembelajaran Matematika Realistik dalam pembelajaran di kelas, diharapkan siswa mampu membangun pemahamannya sendiri dan pembelajaran menjadi lebih bermakna. Serta dapat meningkatkan kemampuan siswa dalam pemecahan masalah kehidupan sehari-hari, khususnya yang melibatkan pecahan desimal.

Berdasarkan uraian diatas, peneliti tertarik dan termotivasi untuk melakukan penelitian dengan mengangkat judul, "Pengembanga Perangkat Pembelajaran Penjumlahan dan Pengurangan Pecahan Desimal Untuk Kelas V Sekolah Dasar dengan Pendekatan Matematika Realistik"

\section{KAJIAN PUSTAKA}

\section{A. Pembelajaran Matematika}

Seseorang dikatakan belajar matematika, apabila pada diri siswa terjadi suatu kegiatan yang dapat mengakibatkan perubahan tingkah laku yang berkaitan dengan matematika.. secara umum, perubahan tingkah laku tersebut dapat bersifat pengetahuan (kognitif) dan ketrampilan (psikomotor) maupun yang menyangkut nilai dan sikap (afektif). Misalnya seorang siswa belajar definisi suatu konsep dari yang tidak tahu sebelumnya menjadi 
tahu, menggunakan definisi tersebut untuk mempelajari materi selanjutnya siswa serta dapat menerapkannya dalam kehidupan sehari-hari.

Mempelajari matematika hendaknya mengetahui hakekat matematika. Banyak ahli matematika yang merumuskan hakekat matematika dengan cara pandang masing-masing. Hudoyo (dalam Arifin, 2010:10) menyatakan, matematika adalah suatu alat untuk mengembangkan cara berpikir. Pandangan ini menjelaskan bahwa matematika berkaitan dengan gagasan terstruktur yang hubungannya diatur secara logis. Soedjadi (dalam Arifin, 2010:11) mengidentifikasi beberapa karakter khusus matematika yaitu: 1) memiliki obyek kajian abstrak; 2) bertumpu pada kesepakatan; 3) berpola pikir deduktif; 4) memiliki simbol yang dapat diartikan secara fleksibel; 5) memperhatikan semesta pembicaraan; dan 6) konsisten dalam sistem.

Kegiatan pembelajaran matematika merupakan suatu kegiatan belajar mengajar yang sengaja dilakukan untuk membantu siswa mengkontruksi konsep-konsep atau prinsip-prinsip matematika dengan kemampuannya sendiri.melalui proses internalisasi. Konsep-konsep itu terkait dengan pengukuran (termasuk kalkulasi), bentukbentuk, pola-pola dan struktur-struktur, serta penalaran logis yang dikembangkan secara deduktif. Karena itu dalam kegiatan pembelajaran matematika dibutuhkan pembelajaran bermakna bagi siswa.

\section{B. Pecahan Desimal}

Menurut Post (1992), pecahan desimal dapat dipandang dari dua perspektif yakni aspek sistem nilai tempat dengan basis sepuluh dan konsep pecahan. Ditinjau dari sistem nilai tempat dengan basis 10 , pecahan desimal mencakup persepuluhan, perseratusan, perseribuan, dst. Ditinjau dari konsep pecahan, pecahan desimal dapat dihubungkan dengan bagian suatu daerah (area-based part whole intrepretation). Dalam hal ini suatu daerah dibagi atas sepuluh bagian atau seratus bagian atau seribu bagian dst. Misalkan kemampuan memahami nilai tempat untuk pecahan desimal.

Kemampuan menyatakan nilai tempat dari angka-angka pada pecahan desimal, dapat dilihat dari kemampuan menyatakan nilai tempat yang sesuai dengan posisi angka pada pecahan desimal.

\section{Pendekatan Pendidikan Matematika Realistik}

Soedjadi (2001:2) mengemukakan bahwa Pendidikan Matematika Realistik Indonesia (PMRI) pada dasarnya adalah pemanfaatan realita dan lingkungan yang dipahami peserta didik untuk memperlancar proses pembelajaran matematika, sehingga mencapai tujuan pendidikan matematika yang lebih baik

\section{Prinsip Pembelajaran Matematika Realistik Indonesia (PMRI)}

Menurut Gravemeijer (1994:90-91) dalam pembelajaran matematika yang menggunakan pendekatan matematika realistik terdapat tiga prinsip utama, yaitu:

a). Penemuan kembali terbimbing (guided reinvention) dan matematisasi progresif (progresif mathematization). Menurut prinsip reinvetion bahwa dalam pembelajaran matematika perlu diupayakan agar siswa mempunyai pengalaman dalam menemukan sendiri berbagai konsep, prinsip atau prosedur, dengan bimbingan guru.

b). Fenomenologi didaktis (didactical phenomenology) yaitu para siswa dalam memperlajari konsepkonsep, prinsip-prinsip atau materi lain yang terkait dengan matematika bertolak dari masalah-masalah kontekstual yang mempunyai berbagai kemungkinan solusi, atau setidaknya dari masalahmasalah yang dapat dibayangkan siswa sebagai masalah nyata.

c). Mengembangkan model-model sendiri (self-develop model), dalam mempelajari konsep-konsep, prinsipprinsip atau materi lain yang terkait dengan matematika dengan melalui masalah-masalah kontekstual, siswa perlu mengembangkan sendiri model-model atau cara-cara menyelesaikan masalah tersebut.

\section{Karakteristik Pendidikan Matematika Realistik}

Gravemeijer (1994) mengemukakan lima karakteristik Pendidikan Matematika Realistik sebagai berikut:

a. Menemukan masalah kontekstual (the use of context)

Pembelajaran diawali dengan menggunakan masalah kontekstual, tidak dimulai dari sistem formal.

b. Menggunakan Model (use models)

Model situasi dan model matematika dikembangkan sendiri oleh siswa, sebagai jembatan antara level pemahaman yang satu ke level pemahaman yang lain.

c. Menggunakan kontribusi siswa (students contribution)

Kontribusi yang besar pada proses pembelajaran diharapkan datang dari siswa, artinya semua pikiran siswa diperhatikan.

d. Interaktivitas (Interactivity)

Mengoptimalkan proses pembelajaran melalui interaksi siswa dengan siswa, siswa dengan guru 
dan siswa dengan sarana dan prasarana pembelajaran.

e. Terintegrasi dengan topik lainnya (Intertwining) Struktur dan konsep matematika yang diberikan saling berkaitan, oleh karena itu keterkaitan dan keintegrasian antar topik (unit pelajaran) harus dieksplorasi.

\section{Perangkat Pembelajaran}

Perangkat pembelajaran merupakan kumpulan sumber yang memungkinkan guru dan peserta didik melakukan kegiatan pembelajaran (Khabibah, 2006:48). Semakin baik perencanaan yang dibuat, semakin mudah pelaksanaan pembelajaran, sehingga semakin besar peluang keberhasilan hasil belajar yang dicapai.

Menurut Ibrahim (2003:3), perangkat pembelajaran yang diperlukan guru dalam mengelola proses belajar mengajar meliputi : silabus, Rencana Pelaksanaan Pembelajaran (RPP), Lembar Kegiatan Siswa (LKS), Tes Hasil Belajar (THB), media pembelajaran, dan buku peserta didik. Dalam penelitian ini perangkat pembelajaran yang dikembangkan adalah, Rencana Pelaksanaan Pembelajaran, Lembar Kegiatan Siswa dan Tes Hasil Belajar. Berikut diuraikan tentang perangkat pembelajaran.

\section{Rencana Pelaksanaan Pembelajaran (RPP)}

Pada penelitian ini akan dikembangkan dua buah rencana pelaksanaan pembelajaran. Komponen-komponen dalam perencanaan pelaksanaan pembelajaran meliputi:

a. Identitas Sekolah meliputi :

b. KI (Kompetensi Inti)

c. KD (Kompetensi Dasar).

d. Indikator pencapaian kompetensi

e. Tujuan pembelajaran

f. Materi pembelajaran

g. Kegiatan pembelajaran

h. Penilaian.

i. Media/alat, bahan dan sumber belajar.

\section{Lembar Kerja Siswa (LKS)}

Komponen-komponen LKS meliputi: a) judul, b) tujuan pembelajaran, c) uraian materi secara singkat, c) petunjuk mengerjakan contoh-contoh soal dan latihan mandiri, d) pertanyaan-pertanyaan dan kesimpulan.

\section{Tes Hasil Belajar (THB)}

Tes Hasil Belajar (THB) yang dikembangkan dalam penelitian ini berbentuk soal uraian yang berpedoman pada tujuan pembelajaran yang telah dirumuskan. Kelengkapan sebuah tes terdiri dari a) lembar tes, b) lembar jawaban tes, c) kunci jawaban tes dan d) pedoman penilaian.

\section{METODE}

Jenis penelitian dalam rancangan penelitian ini adalah penelitian pengembangan. Model pengembangan perangkat perangkat yang digunakan dalam penelitian ini adalah model Plomp yang terdiri dari lima fase yaitu: (1) fase investigasi awal, (2) fase design, (3) fase realisasi, (4) fase tes, evaluasi dan revisi, (5) fase implementasi.

Subjek penelitian terdiri dari kelas uji coba dan kelas implementasi. Untuk kelas uji coba akan dilaksanakan di kelas VA SDIT Al Ibrah dengan 29 siswa dan untuk kelas implementasi dilaksanakan di kelas VB SDIT Al Ibrah dengan 28 siswa.

Sebelum diimplementasikan, perangkat terlebih dahulu diujicobakan guna mengetahui validitas, reliabilitas, serta sensitivitas butir soal. Instrumen yang digunakan antara lain terdiri dari perangkat pembelajaran, Lembar Kerja Siswa (LKS), Tes Hasil Belajar (THB), instrumen penilaian afektif dan psikomotor, lembar observasi aktifitas siswa, lembar observasi pengelolaan pembelajaran, angket respon siswa dan lembar validasi perangkat pembelajaran.

Data yang telah diperoleh kemudian dianalisis secara deskripsi kualitatif

Adapun metode pengumpulan data yang digunakan antara lain validasi, observasi, tes, dan angket.

\section{HASIL DAN PEMBAHASAN}

\section{Kelayakan}

Berikut penilaian kelayakan perangkat pembelajaran ditunjukkan pada tabel berikut.

Tabel 1 Kelayakan Perangkat

\begin{tabular}{cccc}
\hline RPP & validator 1 & validator 2 & kriteria \\
format & 4.33 & 4.33 & baik \\
Isi & 3.22 & 3.77 & baik \\
bahasa & 3.33 & 4 & baik
\end{tabular}

LKS

\begin{tabular}{cccc} 
format & 4 & 4 & baik \\
Isi & 3.87 & 3.87 & baik \\
bahasa & 4 & 4 & baik \\
\hline
\end{tabular}

Untuk Tes Hasil Belajar dari segi materi, bahasa dan penulisan soal mendapat penilaian valid dan dapat digunakan.

Dengan demikian perangkat pembelajaran layak untuk digunakan

\section{Kepraktisan}

Dari data dalam pelaksanaan kelas ujicoba diperoleh. 
a. Data kemampuan guru mengelola pembelajaran dapat dilihat pada tabel dibawah ini.

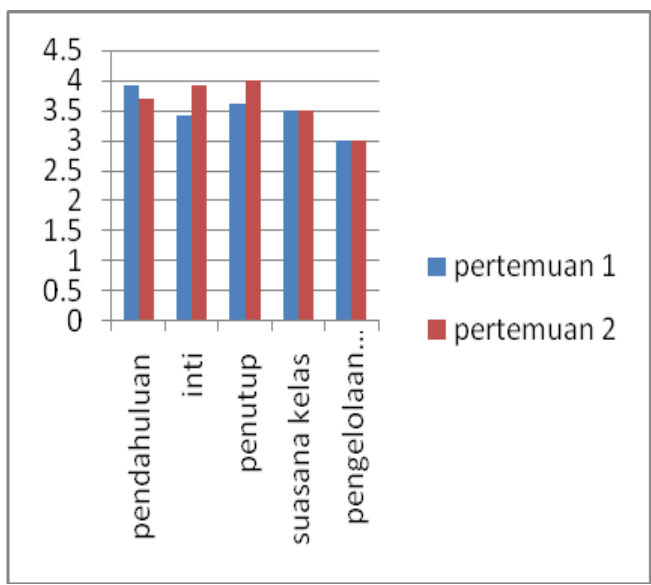

Grafik 1 Data Kemampuan Guru

Dari data diatas, terlihat kemampuan guru dalam pengelolaan kelas dalam kriteria baik.

b. Data Aktivitas Siswa.

Dapat dilihat pada tabel dibawah ini.

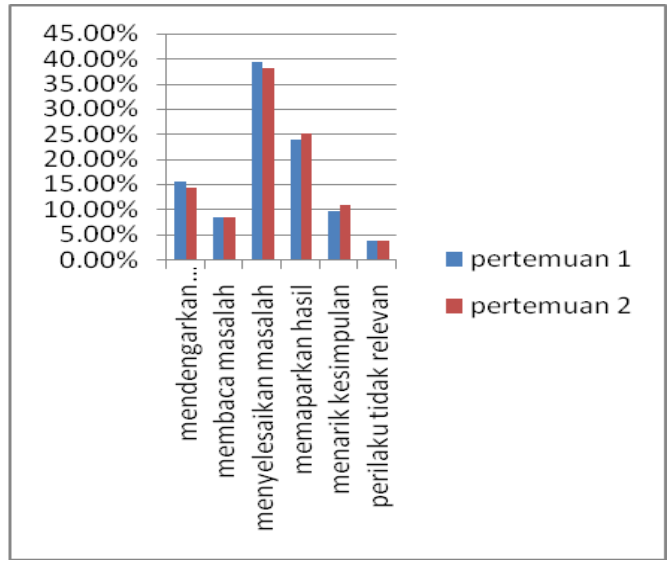

Grafik 2 Data Aktivitas Siswa

c. Data Hasil Belajar

Secara klasikal, setelah pembelajaran dengan pendekatan matematika realistic mencapai $82,75 \%$. Validitas butir soal dalam kategori valid, reabilitas tes mencapai 0,58 yang artinya valid dan butir soal baik karena sensitivitasnya lebih besar atau sama dengan 0.30 .

\section{Keefektifan}

Berdasarkan data yang diperoleh mengenai keefektifan yang dicapai dari ketuntasan belajar secara klasikal, aktivitas siswa dan respon siswa.

Untuk ketuntasan klasikal belajar siswa sebelum pembelajaran adalah $7,14 \%$. Setelah pembelajaran, ketuntasan belajar mencapai $92,85 \%$.
Berikut ini ditunjukkan data yang diperoleh mengenai aktivitas siswa pada kelas implementasi.

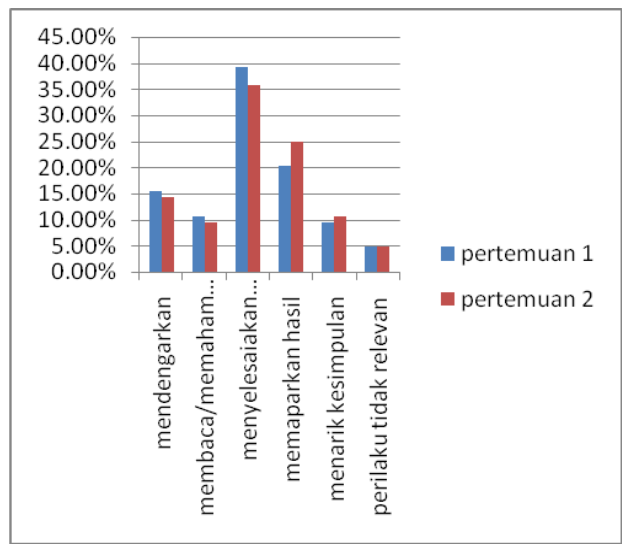

Grafik 3 Data Aktivitas Siswa

Dari data diatas terlihat bahwa aktivitas siswa berada dalam rentang waktu ideal.

Sedangkan data untuk respon siswa dapat dilihat pada tabel dibawah ini

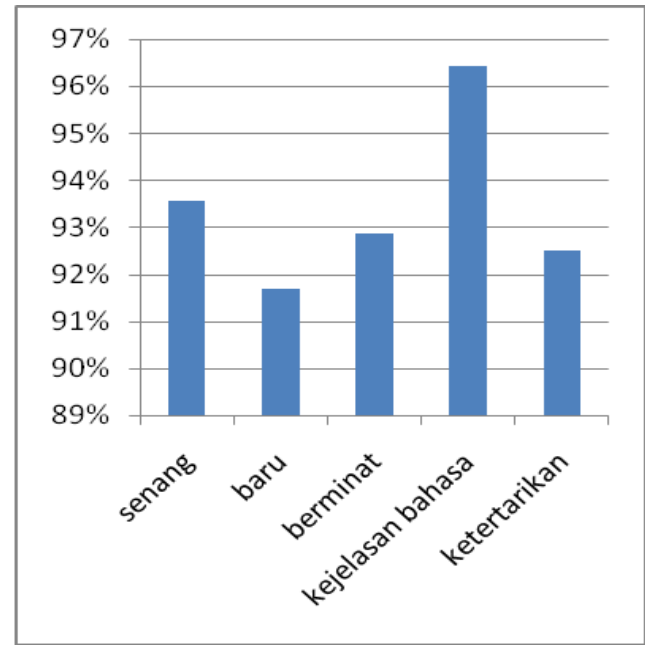

\section{Simpulan dan Saran}

Grafik 4 Respon Siswa

Berdasarkan analisis, pembahasan hasil, dan temuan penelitian, maka dapat disimpulkan bahwa pengembangan perangkat pembelajaran penjumlahan dan pengurangan pecahan decimal dengan pendekatan matematika realistik di kelas V sekolah dasar telah memenuhi syarat kevalidan, kepraktisan, dan keefektifan sehingga layak digunakan dalam proses pembelajaran.

Adapun saran yang diajukan adalah sebagai berikut.

1. Pengembangan perangkat pembelajaran dengan pendekatan matematika realistik dapat digunakan sebagai alternatif pembelajaran pada operasi hitung penjumlahan dan pengurangan pecahan desimal. 
2. Adanya peneliti lain yang akan menindaklanjuti penelitian ini untuk menyempurnakan atau dapat mengurangi kelemahan-kelemahan dalam penelitian ini sehingga diperoleh hasil penelitian yang lebih akurat.

\section{DAFTAR PUSTAKA}

Amin, M. (2006). Pengembangan Buku Panduan Guru untuk Pembelajaran Matematika yang Melibatkan Kecerdasan Intrapribadi dan Interpribadi. Disertasi tidak dipublikasikan. Surabaya: Program Pascasarjana Unesa

Arikunto, S. (2011). Dasar-Dasar Evaluasi Pendidikan. Jakarta: PT. Bumi Aksara

Aqib, Z. (2010). Profesionalisme Guru dalam Pembelajaran.Surabaya: Insan Cendikia

Basuwono, A. (2011). "Pengembangan Perangkat Pembelajaran Matematika dengan Pendekatan PMR Materi Hitung Pecahan di Kelas IV SD”. Tesis Magister Pendidikan. Surabaya:Unesa.

Batlyakru, Y (2015). Pembelajaran Pecahan di Kelas III SD dengan Pendekatan Pembelajaran Matematika Realistik. Tesis Magister Pendidikan Unesa.

De Lange, J. (1987). Mathematics Insight and Meaning. Ultrect:OW\&OC

Gravemeijer, K.P.E. (1994). Developing Realistic Mathematic Education. Freudenthal: Institut Ultrecht.

Gronlund, N.E. (1982). Constructing Achievement Test. Englewood Cliffs: Prentice Hall.

Hadi, S. (2005). Pendidikan Matematika Realistik dan Implementasinya. Banjarmasin: Tulip

Harjanto. (2008). Perencanaan Pembelajaran. Jakarta : Rineka Cipta

Hudoyo, H. (1979). Pengembangan Kurikulum Matematika dan Pelaksanaanya di Depan Kelas. Surabaya: Usaha Nasional

Hudojo, H. (1998). Mengajar Belajar Matematika. Jakarta:BSNP Direktorat Pembinaan

Hudojo, H. (2005). Pengembangan Kurikulum dan Pembelajaran Matematika. Malang: Universitas Negeri Malang

Hobri. (2010). Metodologi Penelitian Pengmbangan. Aplikasi pada Penelitian Pendidikan Matematika. Jember: Pena Salsabila.

Ibrahim, M. (2003). Pembelajaran Kooperatif. Surabaya: Unesa University Press.

Khan, Y. (2010). Pendidikan Karakter Berbasis Potensi Diri. Yogyakarta: Pelangi Publishing
Khabibah, S. (2006). Pengembangan Model Pembelajaran Matematika dengan Soal Terbuka untuk Meningkatkan Kreativitas Peserta Didik Sekolah Dasar. Surabaya: Disertasi tidak dipublikasikan.

Lampiran Permendikbud Nomor 104 Tahun 2014 Tentang Pedoman Penilaian Hasil Belajar Oleh Pendidik

Musser, G.L \& Burger, W.F. (1994). Mathematics for Elementary Teachers. New Jersey: Prentice-Hall

Mukhlis. (2005). Pembelajaran Matematika Realistik Untuk Materi Pokok Perbandingan di Kelas VII SMP Negeri Palangga. Tesis Magister Pendidikan Unesa.

Nieveen. (1999). "Prototyping to Reach Product Quality". University of Twenty, The Nederlands.

Post, T. (1988). Teaching Rational Number and Decimal Concept. Allyn and Bacon, Inc

Plomp, T \& Nieveen, N. (1997).’Education Design: Introductional" in Tjeer Plomp (Ed). System Design: Introductional. Design Approaches and Tools in Educational \& Training. The Netherlands: Kluwer Academic Publisher

Plomp, T. (1997). Educational and Training System Design. Netherland: Faculty of Educational Scince and Technology, University of Twente

Rohani, A. (2004). Pengelolaan Pembelajaran. Jakarta: Rineka Cipta

Ratumanan, T.G. (2004). Belajar dan Pembelajaran: Surabaya: Unesa Press

Soedjadi, R. (1999). Dasar-Dasar Matematika. Surabaya: IKIP Surabaya Press.

Soedjadi, R. (2000). Kiat Pendidikan Matematika di Indonesia. Jakarta: Dirjen Dikti Depdiknas

Soedjadi, R. (2001). Pemanfaatan Realitas dan Lingkungan dalam Pembelajaran Matematika. Makalah disampaikan pada Seminar Nasional di FMIPA Unesa tanggal 24 Pebruari 2001

Slavin, R.E. (1994). Educational Psycology: Theory and Practice. Eight Edition. Massachusetts: Allyn and Bacon Publisher

Suherman, dkk. (2003). Strategi Pembelajaran Kontemporer. Jakarta : Universitas Pendidikan Indonesia.

Suwarsono, S. (2001). Beberapa Permasalahan yang Terkait dengan Upaya Implementasi Pendekatan Matematika Realistik di Indonesia. Makalah disajikan pada Seminar Nasional tentang Pendekatan Matematika Realistik di Universitas Sanata Darma tanggal 14-15 Nopember 2001.

Tim Penyusun Kamus Pusat Bahasa. (2006). Kamus Besar Bahasa Indonesia. Jakarta: Balai Pustaka 
Tiro, M.A. (2010). Cara Efektif Belajar Matematika. Makassar: Andira Publisher

Treffers, A. (1991)."Didactical Background of a Mathematic Programs for Primary Education" dalam L.Streetfland (Ed): Realistic Mathematics Education in Primary School. The Netherland:Ultecht University.

Trianto. (2007). Model-Model Pembelajaran Inovatif Berorientasi Konstuktivis: Konsep, Landasan Teoritis-Praktis dan Implementasinya. Jakarta: Penerbit Prestasi Pustaka.

Triyana, W.I. (2011). Keefektifan Kooperatif Tipe TGT (Team Game Tournament) pada Aritmatika Sosial di Kelas VII SMP Zainuddin. Tesis Magister Pendidikan Unesa. Surabaya: Pps. Unesa.

Trisna, B. (2005). Pembelajaran Matematika Realistik untuk Materi Pokok Persamaan Garis Lurus di Kelas VII SMP Negeri 1 Sukamara. Tesis Magister Pendidikan tidak dipublikasikan

Uno, B.H. (2011). Model Pembelajaran, Menciptakan Proses Belajar Mengajar yang Kreatif dan Efektif. Jakarta : Bumi Aksara

Van den Akker. (1999). Principles and Mathods of Development Resech. The Netherland: University of Twente.

Wijaya, A. (2012). Pendidikan Matematika Realistik Suatu Alternatif Pembelajaran Matematika. Yogyakarta: Graha Ilmu. 